\title{
Pilot-scale purification of $\alpha$-lactalbumin from enriched whey protein concentrate by anion-exchange chromatography and ultrafiltration
}

\author{
Xiao Lu Geng • Alexander Tolkach • Jeanette Otte • \\ Richard Ipsen
}

Received: 20 October 2014 / Revised: 27 January 2015 / Accepted: 5 February 2015 / Published online: 27 March 2015

(C) INRA and Springer-Verlag France 2015

\begin{abstract}
A method based on anion exchange chromatography (AIEX) in combination with ultrafiltration (UF) was developed to obtain kilogram-scale amounts of bovine $\alpha$-lactalbumin $(\alpha-\mathrm{La})$ of high purity from $\alpha$-La-enriched whey protein concentrate ( $\alpha \mathrm{WPC}$ ). Initially, $\alpha$-La was successfully purified, at laboratory scale, from a $10 \%$ solution of $\alpha$ WPC. Removal of casein and denatured whey protein by acid precipitation resulted in a $\alpha$-La purity of $78 \%$. A further purification by AIEX eluting with sodium acetate $(\mathrm{NaAc})$ buffer led to a final purity and recovery of 100 and $85 \%$, respectively. Based on this, the process was simplified and optimized for pilot-scale purification by selective binding of $\beta$-lactoglobulin ( $\beta$ Lg). Batchwise expanded bed AIEX using a column with $5 \mathrm{~L}$ of Q Sepharose matrix was performed. Pure $\alpha$-La was obtained in the run through buffer. In the end, $1100 \mathrm{~g}$ of holo form $\alpha$-La was obtained with a purity of $97.4 \%$ in protein and a recovery of $80 \%$, calculated based on the protein detectable in reversed phase high-performance liquid chromatography (RP-HPLC). Thus, by combining AIEX and UF, heating was avoided allowing production of $\alpha$-La in kilo-scale with high purity and recovery from $\alpha \mathrm{WPC}$ with a minimum volume of buffer solutions.
\end{abstract}

Keywords Bovine $\alpha$-lactalbumin · Purification · Anion exchange chromatography · Ultrafiltration

\footnotetext{
X. L. Geng $(\bowtie) \cdot J$. Otte $\cdot$ R. Ipsen

Department of Food Science, University of Copenhagen, Rolighedsvej 30, 1958 Frederiksberg, Denmark e-mail: xig@food.ku.dk
}

\section{Present Address:}

A. Tolkach

BMI Bayerische Milchindustrie eG, Klötzlmüllerstraße 140, 84034 Landshut, Germany 


\section{Introduction}

In bovine milk, $\alpha$-lactalbumin ( $\alpha$-La) is one of the principal whey proteins and constitutes $\sim 20 \%(w / w)$ of the total whey protein or $3.5 \%$ of total milk protein (Fox and McSweeney 1998). It is a small (14.2 kg.mol ${ }^{-1}$ ), acid (pI 4.2), and compact globular, metal binding (one $\mathrm{Ca}^{2+}$ per mole) protein, consisting of 123 amino acids in a single chain, with four di-sulphide bonds and no free thiol groups. Its structure and functionality have been extensively studied (Chatterton et al. 2006; Madureira et al. 2007; Barbana et al. 2011). $\alpha$-La functions as a coenzyme for synthesis of lactose in the lactating mammary gland. When isolated, it has also been shown to possess a wide range of biofunctionalities, such as improved cognitive functioning (Booij et al. 2006; Markus et al. 2005; Schmitt et al. 2005) and anticancer properties when forming complexes with oleic acid (Svensson et al. 2003). Furthermore, it represents the best characterized model of the intermediate folding structure, the molten globule state, formed upon removal of $\mathrm{Ca}^{2+}$ by lowering the $\mathrm{pH}$ to below 4 , or by using chelating agent such as EDTA at neutral pH (Kuwajima 1996). In addition, $\alpha$-La has been shown to form nanotubular structures upon limited proteolysis (Ipsen et al. 2001a), which in turn can result in formation of strong transparent gels and provide the possibility for $\alpha$-La to be used as a thickening agent or gelling agent in food systems or for encapsulation of bioactive compounds (Ipsen and Otte 2007). However, this nanostructure only forms when $\alpha$-La occurs in high purity without the presence of $\beta$-Lg (Ipsen et al. 2001b). Hence, in order to study the conditions for formation of $\alpha$-La nanostructures and their potential application, pure, native $\alpha$-La should be available in the kilogram scale.

The methods applied to obtain enriched fractions or purified $\alpha$-La have recently been reviewed by Kamau et al. (2010) and El-Sayed and Chase (2011). Extraction of $\alpha$ La with high purity is not an easy task, especially at large- or pilot-scale purification, primarily due to the presence of the other major whey protein $\beta$-lactoglobulin $(\beta-\mathrm{Lg})$. The amount of $\beta$ - $\mathrm{Lg}$ in milk is almost 2.5 times higher than that of $\alpha$-La, and the two proteins have molecular weights in a similar range $\left(\sim 14-18 \mathrm{~kg} \cdot \mathrm{mol}^{-1}\right)$. However, the isoelectric point, net charge, heat and enzyme sensitivity are different enough for separation to be feasible. A summary of studies aiming to purify $\alpha$-La in a large scale is given in Table 1. Isolation of $\alpha$-La from milk or whey protein can be achieved based on three principles. Selective precipitation of $\alpha$-La or $\beta$-Lg was developed during the 1980s (Pearce 1983), and it is a popular method both in lab and pilot scale. By lowering the $\mathrm{pH}$ to around the isoelectric point of $\alpha$-La, with mild heating (around $50{ }^{\circ} \mathrm{C}$ ), $\alpha$-La precipitates together with other minor whey proteins. Further washing and re solubilisation of the precipitate can be used to isolate $\alpha$-La. Such a process is relatively simple and easy to apply, although the purity of $\alpha$-La is normally low, around $20-89 \%$ (Lucena et al. 2006; Alomirah and Alli 2004). Although Tolkach et al. (2005) have successfully achieved an $\alpha$-La preparation with a purity of $98 \%$ by heating whey protein concentrate (WPC) to induce aggregation of $\beta-\mathrm{Lg}$, the quantity of pure $\alpha$-La was only a few grams. A recent study by Toro-Sierra et al. (2013) used thermal aggregation, membrane separation, and a resolubilization technique to purify $\alpha$-La at a large scale, but the purity was somewhat lower (91.3\%). Another strategy is based on the different sensitivity of the whey proteins to enzymatic digestion. Schmidt and Poll 
Table 1 Summary of studies on pilot- or large-scale purification of bovine $\alpha$-lactalbumin ( $\alpha$-La)

\begin{tabular}{llllll}
\hline Method & $\begin{array}{l}\text { Starting } \\
\text { material }\end{array}$ & $\begin{array}{l}\text { Purity } \\
(\%)\end{array}$ & $\begin{array}{l}\text { Recovery } \\
(\%)\end{array}$ & $\begin{array}{l}\text { Amount of } \\
\alpha-L a(g)\end{array}$ & Reference \\
\hline Precipitation & WPI & 91 & $60-80$ & $\sim 500$ & Toro-Sierra et al. (2013) \\
Precipitation & WPC & 74 & 86 & $\sim 20$ & Lucena et al. (2006) \\
Precipitation and chromatography & Liquid whey & $38-54$ & Low & $\sim 2000$ & Outinen et al. (1996) \\
Precipitation & Liquid whey & $52-83$ & 6 & - & Gesan-Guiziou et al. (1999) \\
Enzymatic digestion & WPC & $90-95$ & 15 & $\sim 100$ & Konrad and Kleinschmidt (2008) \\
Anion exchange & Raw milk & 100 & - & $\sim 400$ & Kristiansen et al. (1998) \\
Gel filtration & WPC & Low & Low & $\sim 20$ & Forsum et al. (1973) \\
\hline
\end{tabular}

$W P C$ whey protein concentrate, $W P I$ whey protein isolate

(1991) reported that native $\alpha$-La was highly resistant to trypsin while $\beta$-Lg was not. At lab scale, tryptic hydrolysis of $\beta$ - Lg and discarding the fractions by membrane filtration seem suitable for achieving $100 \%$ purity of $\alpha$-La (Lisak et al. 2013; Cheison et al. 2011); however, when upscaling, the purity drops to $90-95 \%$ and the recovery is quite low (Konrad and Kleinschmidt 2008). In order to achieve high purity, both at laboratory and pilot scale, chromatographic methods seem to be the best choice (Gurgel et al. 2000; Ye et al. 2000; Kristiansen et al. 1998), and most often ion exchange chromatography is used. At lab scale, the bound proteins are usually eluted by increasing concentrations of salt or by altering the $\mathrm{pH}$ of the eluting buffer. The method is limited by the binding capacity of ion-exchange resins, high costs, and requirement of high amounts (thousands of liters) of elution buffer for producing $1 \mathrm{~kg}$ pure $\alpha$-La (Kristiansen et al. 1998). Although ion exchange purification of whey proteins can also be performed using charged ultrafiltration membranes (Arunkumar and Etzel 2014 ), this process has not been upscaled, and the purity of the $\alpha$-La obtained (around $87 \%$ ) was inferior to the level reached by traditional chromatographic methods.

The aim of this study was to produce pure $\alpha$-La in amounts above $1 \mathrm{~kg}$ using a simple and gentle process. For this purpose, a process was developed and optimized for batchwise expanded bed anion exchange chromatography (AIEX) for selective binding of $\beta$-Lg and stepwise elution to recover $\alpha$-La with a minimum consumption of eluting buffer. The temperature was kept below $25^{\circ} \mathrm{C}$ and the $\mathrm{pH}$ above the isoelectronic point 4.2 in order to preserve the properties of $\alpha$-La.

\section{Materials and methods}

\subsection{Materials}

Commercial $\alpha$-La-enriched whey protein concentrate ( $\alpha$ WPC; Lacprodan ${ }^{\circledR}$ Alpha-20) from Arla Foods Ingredients, Denmark, was used as raw material for purification. According to the manufacturer's specification, this $\alpha$ WPC contains a minimum of $60 \%$ $\alpha$-La in total protein and maximum 3\% lactose and 2\% fat. Q Sepharose ${ }^{\circledR}$ Fast Flow 
resin (Pharmacia, Uppsala, Sweden) was used for the AIEX processes. All other chemicals used in this study were of analytical grade.

\subsection{Laboratory-scale purification of $\alpha$-La}

For laboratory-scale purification, $16 \mathrm{~mL}$ of resin was packed in a HiLoad TM $\mathrm{Q}$ Sepharose $^{\circledR}$ Fast Flow, XK 26/10 column (Pharmacia, Uppsala, Sweden), and fitted in a Pharmacia fast-performance liquid chromatography (FPLC) system (Pharmacia LKB, Uppsala, Sweden). The $\alpha$ WPC powder was dissolved at $10 \%(w / w)$ in $100 \mathrm{~mL}$ of demineralized water and stored at $4{ }^{\circ} \mathrm{C}$ overnight. The $\mathrm{pH}$ was adjusted to 4.6 by 1 mol. $\mathrm{L}^{-1} \mathrm{HCl}$, and it was kept at $4{ }^{\circ} \mathrm{C}$ overnight to give precipitation of casein and denatured whey proteins. The solution was then centrifuged at $12,470 \times g$ for $3 \mathrm{~min}$ (Sigma 1-14, Germany) and filtered through filter paper (Grade 42, Whatman ${ }^{\circledR}$, UK) followed by a syringe filter (Frisenette, Denmark) with cellulose acetate membrane and pore size of $0.45 \mu \mathrm{m}$. Before loading on the FPLC system, the $\mathrm{pH}$ was increased to 7 with 1 mol.L $\mathrm{L}^{-1}$ sodium hydroxide $(\mathrm{NaOH})$, and $5 \mathrm{~mL}$ of this pre-purified $\alpha \mathrm{WPC}$ solution was injected onto the AIEX column with a bed volume of $16 \mathrm{~mL}$. Elution of the major whey proteins was achieved by stepwise changes in ionic strength and $\mathrm{pH}$ according to Table 2 . The different $\mathrm{pH}$ values of the 0.2 mol. $\mathrm{L}^{-1}$ sodium acetate $(\mathrm{NaAc})$ buffers were obtained by adding 0.2 mol. $\mathrm{L}^{-1}$ acetic acid with $\mathrm{pH} 3$. The flow rate was $10 \mathrm{~mL}$. $\mathrm{min}^{-1}$ and the UV absorbance was monitored at $280 \mathrm{~nm}$. The $\alpha$-La fraction was collected, weighed, and analyzed by reversed phase high-performance liquid chromatography (RP-HPLC) as described in Sect. 2.5. The fractionation was repeated three times to make sure that it was reproducible.

\subsection{Lab-scale process optimization for pilot-scale purification}

In order to have a clear pre-purified $\alpha \mathrm{WPC}$ solution for pilot-scale purification, a test was made to find the highest concentration of $\alpha \mathrm{WPC}$ that could be used. Five solutions containing various concentrations of $\alpha \mathrm{WPC}(1,2,4,7$, and $10 \% w / w)$ were made by adding $\alpha \mathrm{WPC}$ to $100 \mathrm{~mL}$ of demineralized water. After acidification to $\mathrm{pH} 4.6$ with $1 \mathrm{~mol} . \mathrm{L}^{-1} \mathrm{HCl}$ and storage overnight at $4{ }^{\circ} \mathrm{C}$, without filtration, the particle size of these

Table 2 The process steps for lab-scale anion exchange chromatographic purification of $\alpha$-La from enriched whey protein concentrate $(\alpha \mathrm{WPC})$

\begin{tabular}{|c|c|c|}
\hline Process step & No. of bed volumes & Time (min) \\
\hline $10 \%$ pre-purified $\alpha \mathrm{WPC}, \mathrm{pH} 7.0$ & 0.3 & 0.5 \\
\hline 0.1 mol. $\mathrm{L}^{-1} \mathrm{NaAc}, \mathrm{pH} 7.0$ & 2.7 & 4.7 \\
\hline 0.2 mol. $\mathrm{L}^{-1} \mathrm{NaAc}, \mathrm{pH} 7.0$ & 6.9 & 10.3 \\
\hline 0.2 mol. $\mathrm{L}^{-1} \mathrm{NaAc}, \mathrm{pH} 5.3$ & 4.2 & 7.2 \\
\hline 0.2 mol. $\mathrm{L}^{-1} \mathrm{NaAc}, \mathrm{pH} 4.8$ & 4.2 & 7.2 \\
\hline 0.2 mol. $\mathrm{L}^{-1}$ Acetate, $\mathrm{pH} 3.0$ & 1.8 & 3.2 \\
\hline 1.0 mol. $\mathrm{L}^{-1} \mathrm{NaCl}$ & 1.8 & 3.2 \\
\hline 0.1 mol. $\mathrm{L}^{-1} \mathrm{NaAc}, \mathrm{pH} 7.0$ & 1.8 & 3.2 \\
\hline
\end{tabular}


solutions was measured using a MasterSizer (Malvern Instruments, UK). Each solution was mixed well prior to the measurement.

In order to reduce the elution buffer volume for the pilot-scale purification, the labscale AIEX process was adapted to selectively bind $\beta$-Lg so that $\alpha$-La could be collected in the run-through from the column. This process was initially developed in lab scale using an ion exchange resin with a bed volume of $100 \mathrm{~mL}$ packed in a funnel fitted with filter paper (Grade 42 , Whatman ${ }^{\circledR}$, UK). The resin was regenerated by adding $60 \mathrm{~mL}$ of $1 \mathrm{~mol} . \mathrm{L}^{-1} \mathrm{NaCl}$ and draining by gravity. This was repeated five times. The resin was equilibrated by washing with $60 \mathrm{~mL} \mathrm{NaAc}$ buffer $\left(0.2 \mathrm{~mol} . \mathrm{L}^{-1}, \mathrm{pH} 7\right)$ five times. Before loading, NaAc was added to $60 \mathrm{~mL}$ of pre-purified $\alpha \mathrm{WPC}$ to obtain concentrations between 0.2 and 0.4 mol. $\mathrm{L}^{-1}$, and the $\mathrm{pH}$ was adjusted to 7 with 2 mol. $\mathrm{L}^{-1} \mathrm{NaOH}$. The NaAc- $\alpha$ WPC solution was loaded on the resin in the funnel, drained by gravity, and eluted twice with 0.2 mol.L ${ }^{-1} \mathrm{NaAc}$ buffer at $\mathrm{pH} 7$. Three eluates were collected (i.e., the run-through of NaAc- $\alpha$ WPC solution, and the two eluates with 0.2 mol. $\mathrm{L}^{-1} \mathrm{NaAc}$ buffer) and analyzed by RP-HPLC to determine the purity of $\alpha$-La. In total, five levels of $\mathrm{NaAc}\left(0.2,0.23,0.26,0.3\right.$, and $\left.0.4 \mathrm{~mol} . \mathrm{L}^{-1}\right)$ in the $\mathrm{NaAc}-\alpha \mathrm{WPC}$ sample were tested in triplicate.

\subsection{Pilot-scale purification of $\alpha$-La}

\subsubsection{Preparation of NaAc- $\alpha W P C$ solution}

Large-scale preparation of the NaAc- $\alpha$ WPC solution to be used for AIEX was performed as outlined in Fig. 1. The $\alpha \mathrm{WPC}$ powder $(20 \mathrm{~kg})$ was dissolved in $1000 \mathrm{~L}$ of deionized water in a tank (Finncont Oy, Finland) with agitation for $8 \mathrm{~h}$ and stored overnight at room temperature. On the second day, the $\mathrm{pH}$ was adjusted to 4.6 with $1 \mathrm{~mol} . \mathrm{L}^{-1} \mathrm{HCl}$, and again, the solution was stored overnight at room temperature. The third day, the $1000 \mathrm{~L} \propto \mathrm{WPC}$ solution were subjected to ultrafiltration (UF) using a plant unit (DSS Silkeborg A/S, Denmark). Initially, concentration to $480 \mathrm{~L}$ was achieved using a spiral wound polyethersulfone UF membrane with $10 \mathrm{~kg} \cdot \mathrm{mol}^{-1}$ molecular cutoff and a membrane area of $17 \mathrm{~m}^{2}$ (TriSep Corporation, USA). The concentrated $\alpha$ WPC solution was then separated using a $250 \mathrm{~kg} \cdot \mathrm{mol}^{-1}$ molecular weight cutoff polyvinylidene membrane (Synder Filtration, USA). About $440 \mathrm{~L}$ of permeate was collected and reconcentrated using the $10 \mathrm{~kg} \cdot \mathrm{mol}^{-1}$ molecular cutoff membrane to a final volume of $120 \mathrm{~L}$. In order to remove salts, continuous dia-filtration was performed by pumping deionized water into the feeding tank while the UF process was running. The protein concentration of the permeate was monitored using a MilkoScan ${ }^{\mathrm{TM}}$ FT2 (FOSS, Denmark) during the whole process. From the final $120 \mathrm{~L}$ of pre-purified $\alpha \mathrm{WPC}$, batches of $3 \mathrm{~L}$ were added the desired amount of NaAc to achieve 0.3 mol. $\mathrm{L}^{-1}$ of $\mathrm{NaAc}$ and the $\mathrm{pH}$ was adjusted to 7.0 using $2 \mathrm{~mol} . \mathrm{L}^{-1} \mathrm{NaOH}$. In total, 12 batches $(36 \mathrm{~L})$ of NaAc- $\alpha$ WPC were prepared for AIEX, and the rest $(84 \mathrm{~L})$ of the pre-purified $\alpha \mathrm{WPC}$ solution was stored at $4{ }^{\circ} \mathrm{C}$.

\subsubsection{Batchwise expanded bed AIEX}

For pilot-scale batchwise expanded bed ion exchange chromatography, $5 \mathrm{~L}$ of resin was packed in a column with 25-cm inside diameter (Pharmacia, Uppsala, Sweden), fitted 


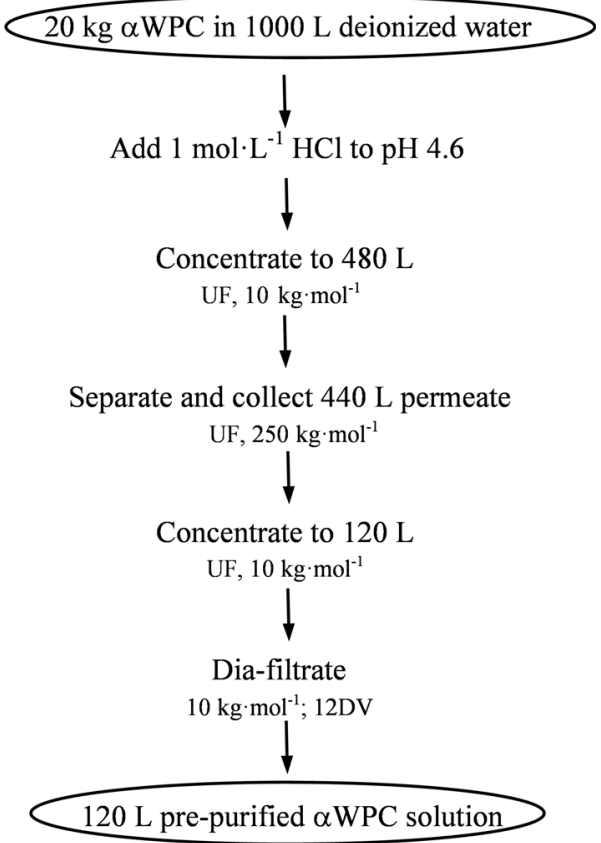

Fig. 1 Pilot-scale preparation of pre-purified $\alpha$-lactalbumin-enriched whey protein concentrates $(\alpha \mathrm{WPCs})$ to be used for pilot-scale anion exchange chromatography

with an agitator $2 \mathrm{~cm}$ above the bottom membrane. The AIEX procedure used is illustrated in Fig. 2. Before loading, the resin was washed with $5 \mathrm{~L}$ of 1 mol. $\mathrm{L}^{-1} \mathrm{NaCl}$, gently stirred for $3 \mathrm{~min}$, and drained by gravity. The procedure was repeated four times and the protein concentration in the eluted $\mathrm{NaCl}$ buffer was $<0.5 \%$ as measured by the MilkoScan $^{\text {TM }}$ FT2 (FOSS, Denmark). Equilibration of the resin was done using the same procedure (five repetitions), but with $5 \mathrm{~L}$ of $0.2 \mathrm{~mol} . \mathrm{L}^{-1} \mathrm{NaAc}$ buffer at $\mathrm{pH} 7$. A 3-L batch of NaAc- $\alpha$ WPC solution was then loaded on the column; stirring was done for 15 min ensuring sufficient absorption of other whey proteins onto the resin and that $\alpha$-La was present in the collected eluate. The column was then washed two times with $3 \mathrm{~L}$ of $0.2 \mathrm{~mol} . \mathrm{L}^{-1} \mathrm{NaAc}$ buffer, $\mathrm{pH} 7$, and the eluate collected. Samples from the first $\mathrm{NaAc}-\alpha \mathrm{WPC}$ run-through and the two subsequent NaAc buffer eluates were analyzed by RP-HPLC for purity and recovery (Sect. 2.5 ). The whole procedure was performed 12 times, and all the eluates were pooled resulting in $108 \mathrm{~L}$ of purified $\alpha$-La solution.

\subsubsection{Post-treatment of the $\alpha$-La solution}

The purified $\alpha$-La solution was subsequently subjected to continuous dia-filtration as described above with 10 dia-filtration volumes (DVs) until the conductivity reached $0.2 \mathrm{mS} . \mathrm{cm}^{-1}$. Final concentration was carried out in a plate-and-frame filtration system (The Danish Sugar Corporation Ltd., Denmark) with membranes having a pore size of $0.4 \mu \mathrm{m}$. The inlet pressure was $3 \mathrm{bar}$, and a flow rate of $4 \mathrm{~m}^{3} \cdot \mathrm{h}^{-1}$ was used. The final 


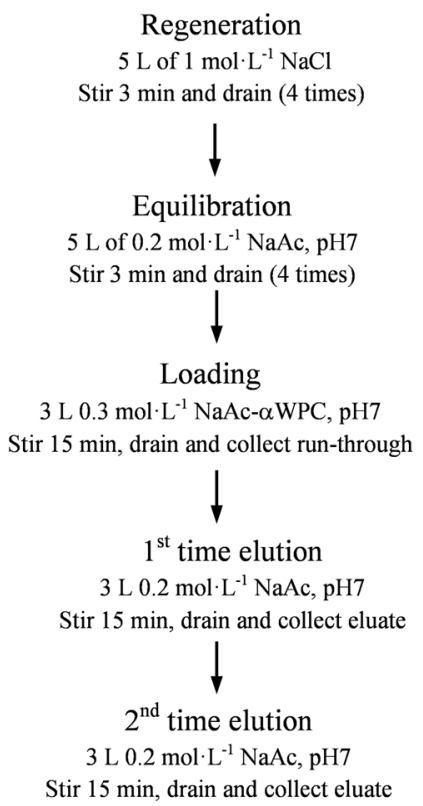

Fig. 2 Schematic outline of the steps performed during pilot-scale batchwise expanded bed anion exchange chromatography for isolation of $\alpha$-La from pre-purified $\alpha \mathrm{WPC}$ with $0.3 \mathrm{~mol} . \mathrm{L}^{-1} \mathrm{NaAc}(\mathrm{NaAc}-\alpha \mathrm{WPC})$. The whole process was performed 12 times, resulting in $108 \mathrm{~L}$ of eluate mixture to be further treated

purified $\alpha$-La concentrate $(11 \mathrm{~L})$ was stored at $4{ }^{\circ} \mathrm{C}$ until freeze drying. For freeze drying, $1 \mathrm{~L}$ of concentrated $\alpha$-La solution was evenly distributed into six petri dishes (20-cm diameter) and frozen at $-45^{\circ} \mathrm{C}$ overnight. The height of the frozen samples was $\sim 10 \mathrm{~mm}$. The frozen samples were immediately transferred to the freeze dryer (Edwards, Bush \& Holm A/S, Denmark) and dried at $-50{ }^{\circ} \mathrm{C}$, for $72 \mathrm{~h}$.

\subsection{Determination of purity and recovery}

The purity and recovery of all the fractions as well as the protein content of the initial whey solution was determined by RP-HPLC fitted with a PLRP-S $300 \AA$ $8 \mu \mathrm{m}$ column (Latek, Eppelheim, Germany). Samples $(5 \mu \mathrm{L})$ were injected and separated at $40{ }^{\circ} \mathrm{C}$ with a flow rate of $1 \mathrm{~mL} \cdot \mathrm{min}^{-1}$ by gradient elution. Solvent A was $0.1 \%(v / v)$ trifluoroacetic acid (TFA) in water, and solvent B consisted of $20 \%$ $(v / v)$ water, $80 \%(v / v)$ acetonitrile, and $0.05 \%(v / v)$ TFA. The gradient started with $45 \%$ of solvent B and increased every $5 \mathrm{~min}$ to $49,51,53$, and $55 \%$, respectively. The column was re-equilibrated with $100 \%$ solvent B for 3 min before returning to the initial conditions. Peaks detection was performed at 210 and $280 \mathrm{~nm}$, and the resulting chromatograms were integrated by Agilent ChemStation software B.02.01 (Agilent technologies, US). The recovery was calculated as the ratio of the peak area of fractionated $\alpha-\mathrm{La}$ to the peak area of $\alpha-\mathrm{La}$ in the initial protein solution 
taking into account the volumes of each. The purity of $\alpha$-La was determined as the ratio of the peak area for $\alpha$-La to the total peak area of all peaks in the chromatogram using the 280-nm molar absorption coefficients for $\alpha$-La and $\beta$-Lg of 20.9 and 9.6, respectively (Pace et al. 1995).

\subsection{Characterization of the final $\alpha$-La powder}

\subsubsection{Gross composition}

The composition of the final $\alpha$-La powder was determined by standard methods. The moisture content was determined by drying at $100 \pm 2{ }^{\circ} \mathrm{C}$ for $4 \mathrm{~h}$ in an oven (Heraeus, Germany) and repeated drying for additional 1-h periods until a stable weight was obtained (FIL-IDF 26:1964). The protein content was obtained by the Kjeldahl method (FIL-IDF 20-1/2:2001) using a conversion factor of 6.38. For ash determination (FILIDF 27:1964), the powder was incinerated at $525 \pm 25{ }^{\circ} \mathrm{C}$ in a muffle furnace for $15 \mathrm{~h}$ and subjected to repeated heating for $1 \mathrm{~h}$ at a time until constant weight was attained. The calcium content was determined according to the IDF standard method (154:1992) by dissolving the remaining ash from the ash analysis in $4 \mathrm{~N} \mathrm{HNO}_{3}$ in a $20-\mathrm{mL}$ volumetric flask and taking $2 \mathrm{~mL}$ of supernatant into a $50-\mathrm{mL}$ volumetric flask, and adding adequate amounts $\mathrm{La}^{2+}$ and Milli-Q water. Atomic absorption spectrometry (PerkinElmer model 3300, USA) was used to detect the absorption of samples, and the calculation was based on a calcium standard curve.

\subsubsection{Molecular weight of $\alpha-L a$}

The molecular weight of the purified $\alpha$-La was measured by liquid chromatographymass spectrometry (LC-MS) essentially as described by Otte et al. (2007) using an Agilent 1100 LC-MSD Trap (Agilent Technologies A/S, Naerum, Denmark) mounted with a Zorbax 300 SB C18 column $(2.1 \times 150 \mathrm{~mm}, 5 \mu \mathrm{m}$, Agilent Technologies A/S). The $\alpha$-La powder was reconstituted to $1 \%$ with water and left overnight at $4{ }^{\circ} \mathrm{C}$. Samples $(5 \mu \mathrm{L})$ were injected into the column and eluted at $40{ }^{\circ} \mathrm{C}$ using a gradient consisting of $15-55 \% \mathrm{~B}$ in $47 \mathrm{~min}$ at a flow rate of $0.25 \mathrm{~mL} \cdot \mathrm{min}^{-1}$. Buffer A was $0.1 \%(v / v)$ TFA in water and buffer B was $0.1 \%(v / v)$ TFA in $90 \%(v / v)$ acetonitrile. The online MS analyses were performed using the standard range from 200 to $2200 \mathrm{~m} / \mathrm{z}$ and the target mass set to $1522 \mathrm{~m} / z$. The molecular weight of the purified $\alpha$-La was determined by deconvolution of an average mass spectrum taken over the peak for $\alpha$-La.

\subsubsection{Maximum denaturation temperature $\left(T_{\max }\right)$}

The maximum denaturation temperature $\left(T_{\max }\right)$ of the purified $\alpha$-La was determined by differential scanning calorimetry (DSC) using a Micro DSC III apparatus (SETARAM, Caluire, France). The purified $\alpha$-La powder was dissolved in water at $50 \mathrm{mg} \cdot \mathrm{mL}^{-1}$ and the $\mathrm{pH}$ was adjusted to 6.5 with $1 \mathrm{~mol} . \mathrm{L}^{-1} \mathrm{HCl}$. The sample $(700 \mu \mathrm{L})$ was placed in the DSC sample chamber and heated at $1{ }^{\circ} \mathrm{C}$ per minute from 25 to $90{ }^{\circ} \mathrm{C}$. The measurements were performed triplicate. 


\section{Results and discussion}

\subsection{Laboratory-scale AIEX purification of $\alpha$-La}

As shown in Fig. 3, the lab-scale process initially applied was successful in giving a retention time for $\alpha$-La around $18 \mathrm{~min}$, nicely separated from $\beta-\operatorname{Lg} B(\sim 30 \mathrm{~min})$ and $\beta$ Lg A ( $\sim 35 \mathrm{~min})$. Thus, using a 0.2 mol. $\mathrm{L}^{-1} \mathrm{NaAc}$ buffer at $\mathrm{pH} 7$ resulted in elution of only $\alpha$-La. By keeping the NaAc buffer at the same concentration but decreasing $\mathrm{pH}$ to 5.3 and 4.8 (Table 2), $\beta$ - $\operatorname{Lg} B$ and $\beta-\operatorname{Lg} A$, respectively, were eluted from the column. The $\alpha$-La fraction was collected by pooling the fractions from 11 to $25 \mathrm{~min}$. The purity of the pooled $\alpha$-La fraction was analyzed by RP-HPLC as shown in Fig. 4 together with the profile of the sample applied. After pre-purification at $\mathrm{pH} 4.6$, mainly $\alpha$-La, $\beta$ $\operatorname{Lg~B}$, and $\beta$-Lg A form were present (Fig. 4a) as any remaining casein and other whey proteins had been denatured during heat treatment in the production of $\alpha \mathrm{WPC}$ and were removed by sedimentation upon adjusting the $\mathrm{pH}$ to 4.6. Mayer et al. (2010) and Tolkach et al. (2005) applying a similar method to treat the initial whey protein solution also achieved removal of bovine serum albumin (BSA) and immunoglobulin. The minor whey proteins, especially BSA and immunoglobulin, like $\beta-\mathrm{Lg}$, both contain free thiol groups, and irreversible denaturation of these already starts at $60{ }^{\circ} \mathrm{C}$ (Vermeer and Norde 2000; Boye et al. 1996). When the $\mathrm{pH}$ is adjusted to 4.6, most or all of the denatured minor whey proteins will be precipitated together with a small amount of denatured major whey proteins (Puyol et al. 1999; Hollar and Parris 1995). Figure 4b shows a typical 280-nm profile of $\alpha$-La. A very similar profile was obtained at $210 \mathrm{~nm}$ (data not shown). The minor peaks found on both sides of the main peak were also seen by Toro-Sierra et al. (2013) and Cheison et al. (2012) who purified $\alpha$-La from whey protein isolates. Heat treatment during milk and whey processing promote protein lactosylation causing the molecule to be more hydrophilic and elute earlier in RPHPLC (Thomsen et al. 2012; Lund et al. 2005). Accordingly, the small peaks before the main peak for $\alpha$-La are expected to contain mono-lactosylated $\alpha$-La. The small peak appearing after the main $\alpha$-La peak is believed to be another slightly modified form of

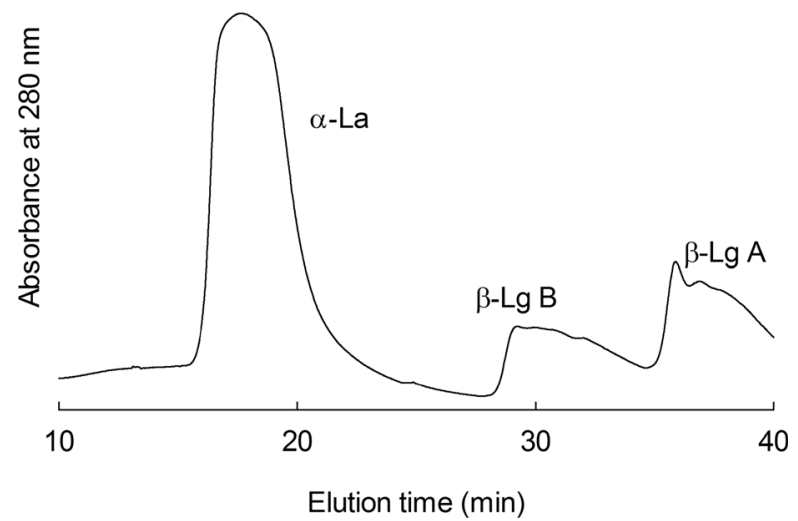

Fig. 3 Elution profile from the lab-scale anion exchange chromatography (AIEX) of 10\% pre-purified $\alpha$ WPC. Elution steps are shown in Table 2 


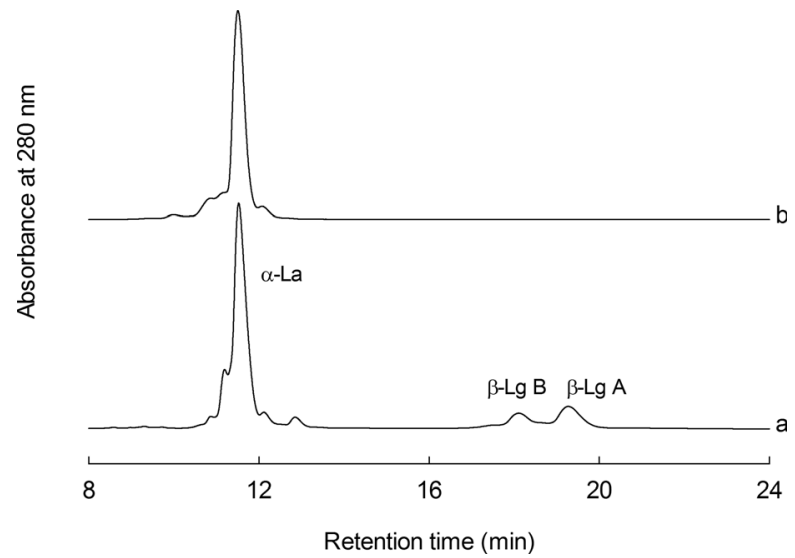

Fig. 4 RP-HPLC chromatograms of the initial 10\% pre-purified $\alpha \mathrm{WPC}$ solution loaded (a) and the $\alpha$-La fraction collected (b) from the lab-scale AIEX shown in Fig. 3

$\alpha$-La. By integration of the resulting peaks, the purity of $\alpha$-La reached $100 \pm 0 \%$, and the recovery was $85.1 \pm 6.4 \%$.

\subsection{Optimization of the particle size prior to UF}

During membrane filtration, the particle size influences the permeability of membranes due to the fouling and hence affects the purification result. When upscaling the process, the $10 \%(w / w)$ pre-purified $\alpha \mathrm{WPC}$ in a volume of $3 \mathrm{~L}$ appeared turbid, indicating that after centrifugation and filtration $(0.45-\mu \mathrm{m}$ pore size), there were still some small particles present in the solution, probably aggregated, denatured whey proteins. Large particles $(\geq 1 \mu \mathrm{m})$ can easily be removed by filtration, but the smaller ones $(\leq 1 \mu \mathrm{m})$ should be avoided in the solution. Turcaud et al. (1990) suggested that particles with diameters near $0.2 \mu \mathrm{m}$ have maximum potential for fouling of membranes as they are too large for both permeation through the UF membrane and transportation back to the solution by Brownian diffusion. On the other hand, they will be too small for the lift force to remove them from the membrane surface (McLaugulin 1993). In order to minimize membrane fouling, the maximal $\alpha$ WPC concentration that could be present in the solution without forming small aggregates was determined. The particle size distribution at five concentrations of $\alpha \mathrm{WPC}$ was measured, and the volume fractions of particles smaller than $1 \mu \mathrm{m}$ in each sample are given in Table 3. It can be seen that solutions containing 1 and $2 \%$ pre-purified $\alpha \mathrm{WPC}$ did not contain such small particles $(0.1-$ $1 \mu \mathrm{m})$. In solutions with concentrations above $2 \%$, intensive particle formation was observed causing a high number of small particles, presumably sterically stabilized, which could not be removed by centrifugation or microfiltration. Therefore, a $2 \% \alpha$ WPC solution was chosen as the starting point for the pilot-scale purification. 
Table 3 The volume fraction of particles with size between 0.1 and $1 \mu \mathrm{m}$ in solutions with various concentrations of $\alpha$-La-enriched whey protein concentrate ( $\alpha \mathrm{WPC}$ )

\begin{tabular}{lc}
\hline$\alpha \mathrm{WPC}(\%, w / w)$ & Volume (\%) \\
\hline 1 & 0 \\
2 & 0 \\
4 & $1.5 \pm 0.2$ \\
7 & $2.9 \pm 0.4$ \\
10 & $4.9 \pm 0.1$ \\
\hline
\end{tabular}

Values are expressed as means $\pm \mathrm{SD}$ from three independent replicates

\subsection{Optimization of batchwise expended bed AIEX at lab scale}

The lab-scale purification method described in Sect. 2.2 provided information about the appropriate conditions for separation of $\alpha-\mathrm{La}, \beta-\mathrm{Lg} B$, and $\beta-\mathrm{Lg} \mathrm{A}$, such as the $\mathrm{pH}$ value, salt concentration, resin capacity, and buffer volume. Keeping the same flux, hence the same time scale for elution, and the same loading capacity, increasing the bed volume from $16 \mathrm{~mL}$ to $5 \mathrm{~L}$ for each batch $(3 \mathrm{~L}, 10 \%$ protein load) would require $120 \mathrm{~L}$ of buffer for elution. From an economical point of view, this would not be optimal. Therefore, it was decided to add NaAc directly into the pre-purified $\alpha$ WPC causing the initial three process steps shown in Table 2 to be transformed into one. The effect of the various $\mathrm{NaAc}$ concentrations, at $\mathrm{pH} 7$, on the purity of the $\alpha$-La fraction collected as the run-through from the column tested at lab scale is shown in Table 4. The best result was obtained when NaAc was added to the pre-purified $\alpha \mathrm{WPC}$ at around $0.3 \mathrm{~mol} . \mathrm{L}^{-1}$, which resulted in a purity of $\alpha$-La of $98.6 \%$. At this NaAc concentration, $\beta$ - $\mathrm{Lg}$ appeared to be the major component interacting with the ion exchange resin. At neutral $\mathrm{pH}, \beta-\mathrm{Lg}$ has a higher negative net charge than $\alpha-\mathrm{La}(-17.6$ and -15.6 for $\beta$-Lg A and $\beta$-Lg B, vs -3.7 for $\alpha$-La; Lucas et al. 1998). At lower concentrations of $\mathrm{NaAc}(0.20$,

Table 4 Purity of $\alpha$-La, when using different NaAc concentrations in the $\alpha$-La-enriched whey protein concentrate $(\alpha \mathrm{WPC})$ applied to the ion exchange column

\begin{tabular}{ll}
\hline $\mathrm{NaAc}\left(\mathrm{mol}^{-1}\right)$ & Purity of $\alpha$-La $(\%)$ \\
\hline 0.20 & $96.6 \pm 0.45^{\mathrm{a}}$ \\
0.23 & $98.0 \pm 0.25^{\mathrm{ab}}$ \\
0.26 & $98.2 \pm 0.20^{\mathrm{bc}}$ \\
0.30 & $98.6 \pm 0.15^{\mathrm{c}}$ \\
0.40 & $97.0 \pm 0.23^{\mathrm{a}}$ \\
\hline
\end{tabular}

Values are the mean of three independent replicates. Values with the same superscript letter are not significantly different $(p>0.05)$ 
0.23 , and $0.26 \mathrm{~mol} . \mathrm{L}^{-1}$ ), the ionic environment did not provide optimum binding of $\beta$ $\mathrm{Lg}$ to the resin; consequently, a small amount of $\beta$-Lg eluted together with $\alpha$-La. On the other hand, when further increasing the salt concentration to 0.4 mol. $\mathrm{L}^{-1}$, excess $\mathrm{Ac}^{-}$may compete with $\beta-\mathrm{Lg}$ for the binding sites, thus starting to displace $\beta$-Lg from the ion exchanger (Kisley et al. 2014). A concentration of $0.3 \mathrm{~mol} \cdot \mathrm{L}^{-1} \mathrm{NaAc}$ was then chosen for the pilot-scale separation.

\subsection{Pilot-scale purification of $\alpha$-La}

Upscaling the process was performed in two main steps: preparation of the NaAc- $\alpha$ WPC solution followed by batchwise expanded bed AIEX (of 3-L portions) performed 12 times. During concentration of the acidified $\alpha \mathrm{WPC}(\mathrm{pH} 4.6)$ from 1000 to $480 \mathrm{~L}$, the protein content of the permeate was monitored and only $0.02 \%$ protein was present in the discarded permeate. The retentate was then UF-treated using a $250 \mathrm{~kg} . \mathrm{mol}^{-1}$ cutoff membrane to remove precipitated casein and denatured whey protein. The retentate appeared milky and was discarded. After concentration of the collected permeate to $120 \mathrm{~L}$ and dia-filtration, the conductivity reached $40 \mu \mathrm{S} . \mathrm{cm}^{-1}$ and the $\mathrm{pH}$ value was increased from 4.6 to 5 . At this $\mathrm{pH}$ value, which is near the isoelectric $\mathrm{pH}$ of $\beta-\mathrm{Lg}$, the solution appeared turbid, indicative of protein aggregation. After adding $0.3 \mathrm{~mol} . \mathrm{L}^{-1} \mathrm{NaAc}$, and adjusting the $\mathrm{pH}$ back to 7 , the solution became clear and was ready for loading on the column.

Based on the optimization of the batchwise expended bed AIEX at lab scale, the whole process was scaled up to 50 times. The bed volume was increased from $100 \mathrm{~mL}$ to $5 \mathrm{~L}$, and the loading capacity from $60 \mathrm{~mL}$ to $3 \mathrm{~L}$. Loading $3 \mathrm{~L}$ of NaAc- $\alpha \mathrm{WPC}$ caused the column bed to expand, i.e., increase the space between the adsorbent particles and thus the bed porosity. Figure 5a shows the protein composition of the NaAc- $\alpha$ WPC solution at $\mathrm{pH} 7$ before loading to the column. There is a large peak for $\alpha$-La and two smaller peaks representing $\beta$ - $\operatorname{Lg} B$ and $\beta$-Lg A, respectively. This profile is almost identical to the one in Fig. 4a. The protein profiles of the eluates collected during the loading step and the two elution steps are shown in Fig. 5b-d, respectively. Based on the peak areas of $\alpha$-La and volumes applied and collected, it was calculated that $70 \%$ of $\alpha$-La ran through the column as the first fraction and only tiny peaks from $\beta-\operatorname{Lg} B$ and $\beta-\operatorname{Lg} A$ (enlarged part) were observed (Fig. 5b). By washing the column twice with $0.2 \mathrm{~mol} . \mathrm{L}^{-1} \mathrm{NaAc}$ at $\mathrm{pH} 7$, another 7 and $3 \%$, respectively, of $\alpha$-La were obtained (Fig. 5c, d), giving a total recovery of $80 \pm$ $1.2 \%$. This recovery based on the AIEX method is satisfactory. It could have been increased by washing more times with $0.2 \mathrm{~mol} . \mathrm{L}^{-1} \mathrm{NaAc}$ at $\mathrm{pH}$ 7, but that would also increase the volume of buffer needed. In total, $1100 \mathrm{~g}$ of $\alpha$-La with a purity of $97.4 \pm 0.4 \%$ in protein was obtained. Although this purity was slightly lower than that obtained at lab scale $(98.6 \%)$, it is still the highest purity found when comparing with other pilot-scale purifications using WPC or WPI as raw material (Table 1). In addition, the total amount obtained $(1100 \mathrm{~g})$ is the highest amount obtained with reasonable purity (Table 1; Toro-Sierra et al. 2013; Konrad and Kleinschmidt 2008; Kristiansen et al. 1998). With the optimized method applied here, the total buffer volume used for recovery of $\alpha$-La was $550 \mathrm{~L}$ (calculations not shown). If the process had been directly upscaled, the buffer volume necessary would have been $1440 \mathrm{~L}$ (120 L per AIEX), similar to what has been reported by Kristiansen et al. (1998). 


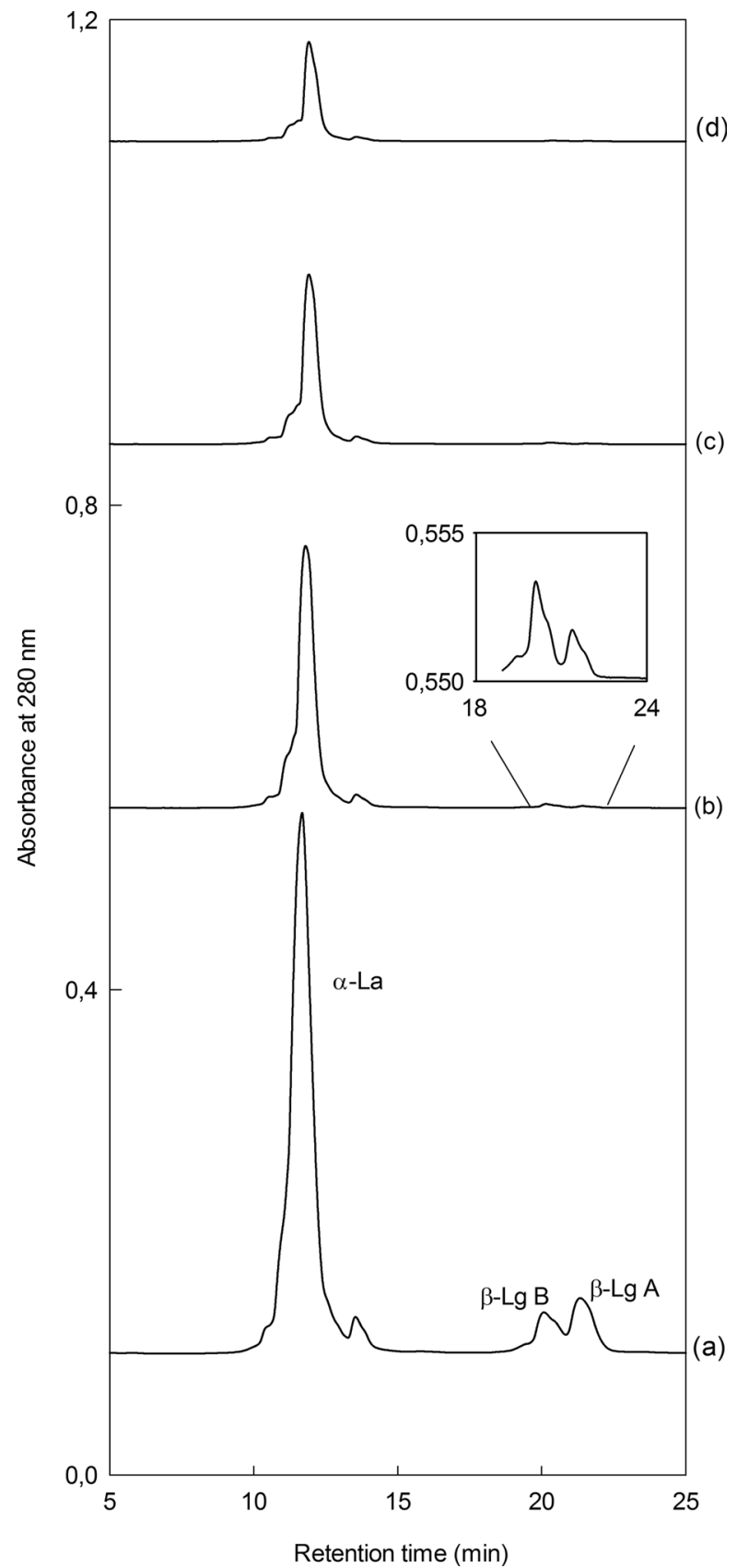

Fig. 5 RP-HPLC chromatograms from the pilot-scale purification of $\alpha$-La showing the NaAc- $\alpha$ WPC solution before loading on the column (a), the run-through from loading of the NaAc- $\alpha$ WPC (b), and the eluates from the first (c) and second elution (d) with 0.2 mol. $\mathrm{L}^{-1} \mathrm{NaAc}$ according to the process outlined in Fig. 2. The insert graph shows an expanded view of the region with $\beta-\mathrm{Lg}$ 
Table 5 Composition (\%) of produced $\alpha$-La powder

$\begin{array}{lr}\text { Dry matter (DM) } & 98.3 \pm 0.4 \\ \text { Protein in DM } & 96.7 \pm 0.5 \\ \alpha \text {-La in protein } & 97.4 \pm 0.4 \\ \text { Ash in DM } & 2.36 \pm 0.15 \\ \text { Calcium in DM } & 0.25 \pm 0.01\end{array}$

Values are expressed as means $\pm \mathrm{SD}$ from three independent replicates

\subsection{Characteristics of the final $\alpha$-La powder}

A summary of the properties of the final $\alpha$-La powder is shown in Table 5. After freeze drying, the dry matter of the powder reached $98.3 \%$, containing $96.7 \%$ of protein in dry matter. The ash $(2.36 \%)$ and calcium $(0.25 \%)$ levels in the powder were similar to those of $\alpha$-La purified by Kristiansen et al. (1998). The molecular weight of the purified $\alpha$-La was $14,177 \mathrm{~kg} \cdot \mathrm{mol}^{-1}$, which is exactly as expected for unmodified $\alpha$-La, and the denaturation temperature $T_{m}$ was $66.1{ }^{\circ} \mathrm{C}$, which corresponds very well with the results obtained by others for the holo form of $\alpha$-La (Konrad and Kleinschmidt 2008; Wang et al. 2006; Tolkach et al. 2005). Moreover, after converting calcium and $\alpha$-La contents into moles, the molar ratio of $\mathrm{Ca}$ to $\alpha$-La was 0.94 , which is very close to 1 . This agrees with the molar ratio for native $\alpha$-La (Fox and McSweeney 1998). The average mass spectrum over all $\alpha$-La peaks showed that the final powder contained $90 \%$ unmodified $\alpha$-La and $10 \%$ monolactosylated $\alpha$-La.

\section{Conclusions}

In this study, $\alpha$-La with purity of $100 \%$ and recovery of $85 \%$ was obtained via a lab-scale AIEX process. When the method was upscaled and modified to selectively bind $\beta$-Lg and recover $\alpha$-La in a small volume, a total amount of $1.1 \mathrm{~kg}$ of $\alpha$-La (in its holo form) with a purity of $97.4 \%$ in protein was obtained with a recovery of $80 \%$ in the AIEX process. This is the highest purity and recovery among all studies on isolation of $\alpha$-La from raw milk or whey protein powders at large or pilot scale. These results confirm that in order to obtain $\alpha$-La in kilo-scale amounts with very high purity and recovery, ion exchange combined with membrane technique is the best solution. On the other hand, large-scale purification of $\alpha$-La has not been extensively reported. One reason is probably due to the limited market for pure, native $\alpha$-La. This work provided a way to obtain large amounts of pure $\alpha$-La which can be used for further studies of biological and functional properties at industrial scale, e.g., for food, infant nutrition, and pharmaceutical applications.

Acknowledgments The authors are grateful to the financial support from University of Copenhagen and to Arla Foods Ingredients Denmark for providing Lacprodan ${ }^{\circledR}$ Alpha-20. We would also like to express our grateful thanks to Anni Nielsen Bager for her help with the gross composition analysis, Kirsten Sjøstrøm for LC-MS analysis, and Søren Olsen for assisting in atomic absorption spectrometry analysis. Special thanks to Kristian Rotvig Kristiansen for discussion about the ion exchange chromatography method during his retirement. 
Conflict of interest The authors Xiao Lu Geng, Alexander Tolkach, Jeanette Otte, and Richard Ipsen declare that there are no competing interests.

Statement of human and animal rights This article does not contain any studies with human or animal subjects performed by any of the authors.

\section{References}

Alomirah HF, Alli I (2004) Separation and characterization of $\beta$-lactoglobulin and $\alpha$-lactalbumin from whey and whey protein preparations. Int Dairy J 14:411-419

Arunkumar A, Etzel MR (2014) Fractionation of $\alpha$-lactalbumin and $\beta$-lactoglobulin from bovine milk serum using staged, poristivelysharged, tangential flow ultrafiltration membranes. J Membr Sci 454:488-495

Barbana C, Sanchez L, Perez MD (2011) Bioactivity of $\alpha$-lactalbumin related to its interaction with fatty acids: a review. Crit Rev Food Sci 51:783-794

Booij L, Merens W, Markus CR, Willem Van der Does AJ (2006) Diet rich in alpha-lactalbumin improves memory inunmedicated recovered depressed patients and matched controls. J Psychopharmacol 20(4): 526-535

Boye JI, Alli I, Ismail AA (1996) Interactions involved in the gelation of bovine serum albumin. J Agric Food Chem 44:996-1004

Chatterton DEW, Smithers G, Roupas T, Brodkorb A (2006) Bioactivity of $\beta$-lactoglobulin and $\alpha$ lactalbumin- technological implications for processing. Int Dairy J 16:1229-1240

Cheison SC, Leeb E, Toro-Sierra J, Kulozik U (2011) Influence of hydrolysis temperature and $\mathrm{pH}$ on the selective hydrolysis of whey proteins by trypsin and potential recovery of native alpha-lactalbumin. Int Dairy J 21:166-171

Cheison SC, Bor EK, Faraj AK, Kulozik U (2012) Selective hydrolysis of $\alpha$-lactalbumin by Acid Protease A offers potential for $\beta$-lactoglobulin purification in whey proteins. LWT Food SciTechnol 49:117-122

El-Sayed MMH, Chase HA (2011) Trends in whey protein fractionation. Biotechnol Lett 33:1501-1511

Forsum E, Hambraeus L, Siddiqi IH (1973) Larger-scale fractionation of whey protein concentrates. J Dairy Sci 57(6):659-664

Fox PF, McSweeney PLH (1998) Milk protein, dairy chemistry and biochemistry, 1st edn. Blackie Academic \& Professional, United Kingdom

Gesan-Guiziou G, Daufin G, Timmer M, Allersma D, van der Horst C (1999) Process steps for the preparation of purified fractions of $\alpha$-lactalbumin and $\beta$-lactoglobulin from whey protein concentrates. J Dairy Res 66:225-236

Gurgel PV, Carbonell RG, Swaisgood HE (2000) Fractionation of whey proteins with a hexapeptide ligand affinity resin. Bioseparation 9:385-392

Hollar CM, Parris N (1995) Factors affection the denaturation and aggregation of whey proteins in heated whey protein concentrate mixtures. J Dairy Sci 78:260-267

Ipsen R, Otte J (2007) Self-assembly of partially hydrolyzed $\alpha$-lactalbumin. Biotechnol Adv 25:602-605

Ipsen R, Otte J, Qvist KB (2001a) Molecular self-assembly of partially hydrolysed a-lactalbumin resulting in strong gels with a novel microstructure. J Dairy Res 68:277-286

Ipsen R, Bülow-Olsen K, Otte J, Qvist KB (2001b) Protease induced gelation of mixtures of $\alpha$-lactalbumin and $\beta$-lactoglobulin. Milchxissenschaft 56(9):492-495

Kamau SM, Cheison CS, Chen W, Liu XM, Lu RR (2010) Alpha-lactalbumin: its production technologies and bioactive peptides. Compr Rev Food Sci Food 9:197-212

Kisley L, Chen JX, Mansur AP, Dominguez-Medina S, Kulla E, Kang MK, Shuang B, Kourentzi K, Poongavanam MV, Dhamane S, Willson RC, Landes CF (2014) High ionic strength narrows the population of sites participating inprotein ion-exchange adsorption: a single-molecule study. J Chromatogr A 1343:135-142

Konrad G, Kleinschmidt T (2008) A new method for isolation of native $\alpha$-lactalbumin from sweet whey. Int Dairy J 18:47-54

Kristiansen KR, Otte J, Ipsen R, Qvist KB (1998) Large-scale preparation of $\beta$ - lactoglobulin A and B by ultrafiltration and ion-exchange chromatography. Int Dairy J 8:113-118

Kuwajima K (1996) The molten globule state of $\alpha$-lactalbumin. FASEB J 10:102-109

Lisak K, Toro-Sierra J, Kulozik U, Bozanic R, Cheison SC (2013) Chymotrypsin selectively digests $\beta$ lactoglobulin in whey protein isolate away from enzyme optimal conditions: potential for native $\alpha$ lactalbumin purification. J Dairy Res 80:14-20 
Lucas D, Rabiller-Baudry M, Millesime L (1998) Extraction of $\alpha$-lactalbumin from whey protein concentrate with modified inorganic membranes. J Membr Sci 148:1-12

Lucena ME, Alvarez S, Menendez C, Riera FA, Alvarez R (2006) $\alpha$-lactalbumin precipitation from commercial whey protein concentrates. Sep Purif Technol 52(3):446-453

Lund MN, Olsen K, Sørensen J, Skibsted LH (2005) Kinetics and mechanism of lactosylation of $\alpha$ lactalbumin. J Agric Food Chem 53:2095-2102

Madureira AR, Pereira CI, Gomes AMP, Pintado ME, Malcata FX (2007) Bovine whey proteins-overview on their main biological properties. Food Res Int 40:1197-1211

Markus CR, Lammers JH, Deutz NE, Messe MH, Riftering N (2005) Everning intake of alpha-lactalbumin increases plasma tryptophan availability and improves morning alertness and brain measures of attention. Am J Clin Nutr 81(5):1026-1033

Mayer HK, Raba B, Meier J, Schmid A (2010) RP-HPLC analysis of furosine and acid-soluble $\beta$-lactoglobulin to assess the heat load of extended shelf life milk samples in Austria. Dairy Sci Technol 90:413-428

McLaugulin JB (1993) The lift on a small sphere in wall-bounded linear shear flows. J Fluid Mech 246(1): 249-265

Otte J, Shalaby SM, Zakora M, Pripp AH, El-Shabrawy SA (2007) Angiotensin-converting enzyme inhibitory activity of milk protein hydrolysates: effect of substrate, enzyme, and time of hydrolysis. Int Dairy J 17 : 488-503

Outinen M, Tossavainen O, Tupasela T, Koskela P, Koskinen H, Rantamäki P, Syväoja E-L, Antila P, Kankare V (1996) Fractionation of proteins from whey with different pilot scale processes. LWT Food Sci Technol 29:411-417

Pace CN, Vajdos F, Fee L, Grimsley G, Gray T (1995) How to measure and predict the molar absorption coefficient of a protein. Protein Sci 4:2411-2423

Pearce RJ (1983) Thermal separation of $\beta$-lactoglobulin and $\alpha$-lactalbumin in bovine cheddar cheese whey. Aust J Dairy Technol 38:144-148

Puyol P, Cotter P, Mulvihill DD (1999) Thermal gelation of commercial whey protein concentrate: influence of $\mathrm{pH} 4.6$ insoluble protein onthermal gelation. Int J Dairy Technol 52(3):81-91

Schmidt DG, Poll JK (1991) Enzymatic hydrolysis of whey protiens: hydrolysis of $\alpha$-lactalbumin and $\beta$ lactoglobulin in buffer solutions by proteolytic enzymes. Neth Milk Dairy J 45:225-240

Schmitt JA, Jorissen BL, Dye L, Markus CR, Deutz NE, Riedel WJ (2005) Memory function in women with premenstrual complaints and the effect of serotonergic stimulation by acute administration of an alphalactalbumin protein. J Psychopharmacol 19(4):375-384

Svensson M, Fast J, Mossberg AK, Düringer C, Gustafsson L, Hallgren O, Brooks CL, Berliner L, Linse S, Svanborg C (2003) Alpha-lactalbumin unfolding is not sufficient to cause apoptosis, but is required for the conversion to HAMLET (human alpha-lactalbumin made lethal to tumor cells). Protein Sci 12:2794 2804

Thomsen MK, Olsen K, Otte J, Sjøstrøm K, Werner BB, Skibsted LH (2012) Effect of water activity, temperature and $\mathrm{pH}$ on solid state lactosylation of $\beta$-lactoglobulin. Int Dairy J 23:1-8

Tolkach A, Steinle S, Kulozik U (2005) Optimization of thermal pretreatment conditions for the separation of native $\alpha$-lactalbumin from whey protein concentrates by means of selective denaturation of $\beta$-lactoglobulin. J Food Sci 70(9):E557-E566

Toro-Sierra J, Tolkach A, Kulozik U (2013) Fraction of $\alpha$-lactalbumin and $\beta$-lactoglobulin from whey protein isolate using selective thermal aggregation, an optimized membrane separation procedure and resolubiliation techniques at pilot plant scale. Food Bioprocess Technol 6:1032-1043

Turcaud VL, Wiesner MR, Bottero JY (1990) Fouling in tangential-flow ultrafiltration: the effect of colloid size and coagulation pretreatment. J Membr Sci 52(2):173-190

Vermeer AW, Norde W (2000) The thermal stability of immunoglobulin: unfolding and aggregation of a multi-domain protein. Biophys J 78(1):394-404

Wang Q, Tolkach A, Kulozik U (2006) Quantitative assessment of thermal denaturation of bovine $\alpha$ lactalbumin via low-intensity ultrasound, HPLC, and DSC. J Agric Food Chem 54:6501-6506

Ye XY, Yoshida S, Ng TB (2000) Isolation of lactoperxidase, lactoferrin, $\alpha$-lactalbumin, $\beta$-lactoglobulin B and $\beta$-lactoglobulin A from bovine rennet whey using ion exchange chromatography. Int J Biochem Cell Biol 32:1143-1150 